\title{
Article \\ Public governance-constraints and challenges for social work practice
}

by

Jorunn Theresia Jessen

Senior Researcher

Norwegian Social Research NOVA, Oslo and Akershus University College

E-mail: jorunn.jessen@nova.hioa.no

\section{Keywords:}

public governance, social work practice, professional autonomy, performance management, constraints

\section{(c) (i) (2)}

This work is licensed under a Creative Commons Attribution-ShareAlike 4.0 International License. 


\section{Abstract}

In the wake of public sector reforms, the work environment of professionals is changing; there is more description of results and outputs and tighter requirements of front-line work. The changes taking place address a shift towards managerial forms of control and organizational regulations in a range of Western countries. However, the new managerial regimes have different consequences for professionals as objects and subjects of governance. This paper investigates the extent of managerial and administrative regulations in the Norwegian social services, questioning the asserted negative impacts on professional autonomy in social work practice. The empirical data derive from a survey conducted among practitioners and managers in 125 local agencies, and compared to bureaucratic rules and agency procedures that set constraints, the new management model allows both autonomy and flexibility in choosing means and measures in various fields. Most of all, collegial support plays a significant role in providing professional standards for decision-making. The increase of management techniques and standard procedures in public administration concurrently challenges social work values, translating the social services into a field of more regulatory practices.

Keywords: public governance, social work practice, professional autonomy, performance management, constraints

\section{Introduction}

In general, public sector governance involves means of achieving direction, control and the coordination of individuals and organizational units on behalf of their common interest (Lynn et al., 2001). However, the administrative tools and means have changed along with several shifts in management structures and welfare reforms. Since the 1980s, a range of OECD countries have reformed their public services in line with the ideas of New Public Management (NPM), taken from private business and economic theories (Hood, 1991'; Christensen \& Lægreid, 2001). The changes described address a shift towards managerial forms of control and organizational regulations in most of the Western countries, including an increase in managing professional discretion (Healy \& Meagher, 2004; Clark, 2005; White, 2009). The work environment of welfare services is changing, thus resulting in more prescriptions of policy, increased management of aims and methods, and more regulation and control 
of procedures, outputs and costs (Clark, 2005). The trend towards the increasing standardization and regulations of practice also represents a shift in management and organization of social work practice (Harris \& White, 2009; Banks, 2013).

Social workers are often characterized as street-level professionals, working in hierarchical public service organizations and within frameworks of rules. They provide public services, legitimize political decisions and new policies, and buffer social conflicts. As street-level professionals, they are characterized as mediators between the state and its citizens, playing a double role as objects and subjects (actors) of governance ${ }^{2}$ (Kuhlman, 2006). Since public governance involves means of achieving the direction, control and coordination of individuals and organizational units, professionals become objects of managerial regimes and new policies for public service delivery. As subjects, however, the professionals play a key role in the translation and interpretation of social policy objectives into service deliveries (Hill, 2005; Hill \& Hupe, 2008). The front-line workers have to interact with- and make decisions about the clients, determine eligibility claims, make options and decide the course of action, characterized as agents of welfare (Jewell, 2007). In their role as institutional agents, professionals have to define, interpret and fulfil the ambitions of government policies and welfare reforms (Scott, 2008).

The binary role of street-level bureaucrats as objects and subjects is embedded in the Norwegian labour and welfare services, reflecting the political administrative control on the one hand, and the local- and professional autonomy on the other. Working in the frontline, they are key players participating in decision-making regarding what services to provide, and how to respond to various issues that arise (Hjörne et al., 2010). Even so, the extent to which technical subordination has occurred in social work practice is much debated in terms of whether discretion is still part of everyday decision-making (Harris \& White, 2009).

Theorists disagree as to the extent that public service reforms and managerial regulations have changed the autonomous position of professionals and restricted their opportunities for making independent decisions (Evans \& Harris, 2004). This paper investigates the degree of managerial and administrative regulations, as well as the constraints and challenges of public governance for social work practice within the 
structural frames of the Norwegian social services. A main issue is to examine the perceived autonomy of social workers as agents of welfare translating policies into practice, and as objects to various forms of organizational and internal occupational control.

\section{The Norwegian social services and welfare reform}

As in several other countries the pressure to increase the capacity and efficiency of public administration and governance has led to organizational public reforms. In Norway, the former National Insurance Administration and the Norwegian Directorate of Labour merged into one central governmental administration (NAV) in partnership with the municipal social assistance services in 2006. The intention of the reform was to bring about a "one-door" policy through a coordination of the three former administrations (NOU 2004:13). The partnership model aimed to combine the principles of local selfgovernment and the ministerial responsibility in order to improve the cooperation and coordination between services (Askim et al., 2010). ${ }^{3}$ The primary goals were to get clients off welfare and into work, to create a more efficient administrative apparatus and to make the administration more service oriented (Prop. 46 (2004-2005).

The reform implies a change towards the whole-of-government approach that has taken place in several countries as a means to achieve shared goals and performance regulation, in addition to bringing about an increased quality of service (Christensen \& Lægreid, 2011). One main intention was to establish comprehensive, integrated and seamless services based on the collaboration level between the governmental employment and insurance services, and the social assistance services. Since the reform was politically designed with a minimum of specific goals, it had to be translated into concrete procedures and routines by local administrators (Askim et al., 2010). The transformation of integrated services into the new joint administration therefore called for managerial interventions, whereas local managers were granted a key function in implementing the reform, and became responsible for the coordination of services and the promotion of the changes required.

The trained core of social workers who administer the Norwegian Social Services is responsible for both financial assistance and assistance in kind. ${ }^{4}$ Different from many other countries, the functions of cash allocation and social work are not separate. 
According to the enactment of the Social Services Act in 1991, the purpose is to promote financial and social security, to improve the living conditions of disadvantaged persons and to prevent social problems. The financial assistance is means-tested, and only granted when the clients have utilized their possibilities to obtain income from work or other social insurance benefits. The social assistance services shall provide a final safety net for individuals in need by ensuring adequate resources and helping clients to become self-supporting. During the reform, a new qualification programme related to social services (KVP) was introduced, targeting the social assistance recipients with substantially reduced work and earning capacity and limited rights to other benefits. The programmes make new demands on the social assistance services to judge and control the behaviour of the recipients of social assistance, as well as to strictly follow-up with these recipients. Social workers are to assess their clients' resources and workcapabilities before attending training programmes and to make individual choices regarding the use of activation requirements and sanctions.

\section{Professional autonomy and discretionary power of front-line workers}

Professions administer a certain type of knowledge in a collegial form of organization with political legitimacy to perform a certain social assignment (Grimen, 2008). As a result of being professionally trained, the practitioners traditionally possess autonomy in their performance of work, having the authority to make independent decisions on certain technical issues such as what tasks to perform, how to carry them out and what the aim of the work should be. Professional autonomy ${ }^{5}$ refers to the freedom of the professional practitioner to make choices and decisions about how to act (Banks, 2004).

According to Freidson (2001), professional employees possess technical autonomy or the right to use discretion and judgement in the performance of their work within certain limits set by the management's resource allocation decisions. Discretion occurs whenever "the effective limits on his [the public official's] power leave him free to make a choice among possible courses of action or inaction" (Davis, 1969:4). In the public welfare services, professionals are formally allocated the freedom to make independent decisions by the authorities, having the official approval to decide a social right or entitlement (Evans, 2010). Hence, deliberate choices regarding policy and governance are influencing social work practice (Hupe \& Hill, 2007). Traditionally, the 
delegation is based on the assumption that the trustee is capable of passing judgement and making reasonable decisions (Molander \& Grimen, 2010). Professional judgement involves the capacity to balance a number of aspects and conditions when making decisions and prescribing the adequate actions to be taken (Styhre, 2013). Professional decision-making and discretionary judgements therefore depend on both the capacity to cognitively process existing information while simultaneously drawing on past experiences. Discretion may potentially serve as an entry point for an unjust and unequal treatment or alternatively permit the tailoring of more equitable and humane responses in accordance with social work values (Fording et al., 2007).

\section{Modes of governance and new tools of management}

According to analysts of public administration, different modes of governance may affect and regulate street-level practice. Some relate to governance structures, and others to specific conditions set by the organization and the professions they belong to (Vincant \& Crothers, 1998). Evetts (2010) distinguishes between two ideal typical forms of professionalism, involving organizational and occupational control of knowledge-based work in the service sector. The organizational form of control incorporates rational-legal forms of authority and hierarchical structures of responsibility. It also involves managerialism and external forms of regulations, standardized work procedures and accountability measures. In contrast, occupational control is characterized by collegial relations and authority, guided by codes of ethics and professional norms in terms of advice given by fellow workers through collective decision-making and discussions within work teams (Svensson, 2010). Based on this assumption, various modes of governance and conditions may influence and regulate social work practice in different ways.

Organizational governance involves different modes in terms of traditional administration and New Public Management reforms. The governance strategies often termed "Progressive public administration" (Hood, 1991) or "hierarchical governance" (Newman, 2005) rest on formal rules of law to secure welfare rights and the equal treatment of citizens, designed to minimize programmatic variation by rule-making, and to increase efficiency and centralize the control often utilized in large public bureaucracies. According to this traditional hierarchical approach, management relies upon minute regulations, administrative routines and standardized forms to exercise a 
structuring influence on the way the rules and situations are handled (Considine \& Lewis, 2010). The organizational control may occur as codified bureaucratic rules and descriptions and built-in technical systems such as standardization of the work process. The intention is to regulate practice and shape the actual decision-making in congruence with official policy (Hupe \& Hill, 2007).

The governance strategies of New Public Management mark a departure from the traditional public administration premises of command control and bureaucratic norms, turning instead to approaches largely constructed around inducements (Brodkin, 2007; 2011). The changes are characterized by managerial control through tighter requirements of front-line staff, budgetary controls and administrative procedures (Pollit \& Bouchaert, 2004; Hood, 1991), concurrently creating more discretionary space for managers (Clarke \& Newman, 1997). The new managerial strategies aim to influence how street-level organizations work, partly by regulating front-line practices through performance-based incentives. The introduction of performance measurements is supposed to gain control over the service production by relying upon standardized forms that may currently curb and regulate front-line discretion. The shift involves a different conception of public accountability, thereby reversing the emphasis from process accountability towards a greater element of accountability in terms of results.

New Public Management (NPM) (Hood, 1991) is characterized by privatization, marketization and manageralism, as well as decentralization and devolution (Christensen \& Lægreid, 2001). The ideology of NPM is a normative system that determines what counts as valuable knowledge, and who is consequently empowered to act in what ways (Brodkin, 2011). The ideas reflect a new set of relationships at the front-line service delivery, including a trend towards an increasing standardization and regulation of practice and the imposition of externally defined output targets (results), making both staff and job seekers more responsive to policy goals (Banks, 2013).

The introduction of New Public Management (NPM) reforms is described by Hood (1991) as a shorthand set of broadly similar administrative doctrines. However, the relative dominance of the NPM reform ideas varies in different countries. In Norway, the management elements are adopted more than market elements (Christensen \& 
Lægreid, 2001). As with many other countries, management by objectives and results (MBOR) is the most widely used public management style (Lægreid et al., 2006). MBOR has supplemented the traditional rule-based mode of governance, and created an integrated model entailing bureaucratic procedures and performance management techniques. However, the Norwegian management model is characterized as a hybrid of traditional rule-oriented administration and New Public Management strategies and tools, enhanced as principles for steering street-level practice (Christensen \& Lægreid, 2011).

After the Norwegian national employment and welfare reform in 2006, performance management has become a dominant principle for steering and control, whereas performance indicators and reporting are major components of this system (ibid). The instruments for this purpose are achievement targets and performance indicators, aspects to promote organizational and managerial objectives. In order to increase effectiveness and improve results, strong leadership is required. Audit and inspection, as well as efficiency indicators, shall ensure that the political and organizational goals are fulfilled, making the welfare services more efficient and more responsive to the demands and preferences of consumers. In order to achieve concrete production targets, performance measurement tools are often used. The aim is to monitor the processing time and increase the number of activation placements and individual plans for the recipients of social assistance and qualification allowances. As a consequence, the role of welfare managers is strengthened in order to maintain budgets and monitor performance and quality of service, and thereby improve results. On the other hand, the NPM elements of devolution and more decentralized decision-making may have a positive impact on social work practice, when taking into account that professional discretion requires contextual knowledge (Lyngstad, 2013). A participatory dialogue with service users may be a strategy to overcome an instrumental approach to social problems.

\section{Professional standards and collective cognition}

In accordance with institutional theory, cultural standards such as norms, professional standards and collective cognition will also affect social work practice. Unlike New Public Management based on rational-legal and hierarchical authority, while collegial authority is based on professional knowledge and ethics, and exercised by occupational practitioners (Svensson, 2010). Social service workers develop shared 
norms and a collective understanding from daily experiences and professional knowledge to help shape their interpretation and provide a common standard for rational action. The professional expertise requires an application to individual cases based on a comprehensive approach and tools of analysis that provide guides for different types of interventions and provisions (Johnson \& Yanca, 2001). This social process has structural implications for how the practitioners will carry out their designated tasks (Lenz, 2008).

In the Norwegian welfare administration, social workers are included in a range of professional relationships with colleagues and co-workers in other parts of the administration. Working in the same collegial structure and settings, social workers are responsive to professional norms and ethical rules when consulting their colleagues about decisions in complex cases regarding social assistance services and interactions with clients. I therefore expect collegial advice and professional standards to affect social work practice by influencing the decisions made by practitioners in an enabling way.

Besides the organizational and occupational control, we assume that the work conditions of social workers have an important impact on practices, judgements and decisions taken at the frontline. Since resources, in terms of disposal time, measures and human resources, are often inadequate for the tasks they are supposed to fulfil, as the situation virtually impels workers and agencies to prioritize between demands and urgent cases. To cope with inadequate resources, work pressures and high caseloads, the front-line staff has to apply informal strategies and coping behaviour (May \& Winter, 2009).

\section{Data and variable constructions}

The empirical data in this article come from a survey conducted among caseworkers and advisors employed in the Norwegian employment and welfare administration (NAV), counting both practitioners and local managers. The research was conducted during the spring of 2011 through a random sample comprising $25 \%$ of all the municipalities in Norway. ${ }^{6}$ The respondents were front-line workers selected from the local NAV agencies situated in the randomly selected municipalities. To obtain a representative sample, the municipalities were stratified into two groups, based on a 
population size above or below 100,000 people, resulting in groups of five and 430 municipalities, respectively. A $25 \%$ sample of municipalities with a population below 100,000 people was randomly selected, and a $40 \%$ sample of the local district administrations in each of the municipalities with a population above 100,000 people was randomly selected.

The data are based on an online questionnaire survey, with a response rate of $60 \%$ $(1,758$ respondents from the three services involved). The sample used in this analysis consists of 627 social workers (respondents) employed in the social assistance services, with a predominance of practitioners (85\%) and a smaller group of local managers (15\%). The gender distribution shows a predominance of female workers (83\%). While the educational level and background of welfare workers in the other NAV services varies, the social services sample consists of trained social workers (professionals). The distributions show that the majority of the practitioners are responsible for handling cases and applications for social benefits (73\%). Additionally, $41 \%$ of the respondents (practitioners) are responsible for the guidance, continuous observation and follow-up of recipients with special needs.

\section{Dependent variables}

The dependent variable captures the dimension of technical autonomy or the opportunity to make discretionary judgements and independent decisions in social work practice (Freidson, 1986). The dimension is measured by an additive index, based on the following two items:

"In my work I have considerable freedom to decide how I will carry out my work." "In my work, I make many decisions on my own."

Both items are ranged on a 4-point scale from 1 ("disagree completely") through 4 ("agree completely"), and are highly correlated ( $r$. = .487). In total, $64 \%$ "agreed" and $19 \%$ "agreed completely" in both statements. The mean score of the two variables are 3.00 and 3.01 , respectively.

\section{Independent variables}

The following variables differentiate between the new managerial mechanisms (outputs and targets, work procedures and routines), the more traditional 
administrative mechanisms (rules and directions) and the other regulatory tools of management. The research questions asked concerning the impact of different forms of organizational control were:

To what extent are you governed by rules and directives?

To what extent are you governed by superior political targets?

My choices and judgements are influenced by work procedures and agency routines ${ }^{7}$ I am instructed to achieve results and production targets.

The two former questions were based on a 5-point scale ranging from 1 ("not at all") to 5 ("a very high degree"). The third statement, concerning work procedures, was based on a 5-point scale ranging from 1 ("not at all") to 5 ("always"), while the last statement was based on a 4-point scale ranging from 1 ("disagree completely") to 4 ("agree completely").

The research statements/questions asked concerning work conditions in terms of a lack of time and inadequate resources were:

- Do you lack the adequate resources needed to complete your tasks?

- I have enough time to get the work done (disposal time).

The first question was based on a 5-point scale ranging from 1 ("never" to 5 ("always"), while the last statement was based on a 4-point scale ranging from 1 ("disagree completely") to 4 ("agree completely").

In addition, the dichotomous variable occupational position distinguishes between the two positions of managers and practitioners.

The research statement asked concerning occupational control in terms of peer influence and professional standards was:

The choices and judgements that I make are influenced by my colleagues

The respondents were asked to indicate to what extent they agreed with each statement, based on a five-point ranging from 1 ("not at all") to 5 ("always").

\section{Method}

To investigate the impact of various organizational and occupational modes of governance on social work practice, we use an Ordinary Least Square (OLS) 
regression, controlling for the independent variables referred to, and for individual characteristics (age, gender, position and work experience). In the linear regression analysis, the two following research variables: 1) "I have considerable freedom to decide how I will carry out my work" and 2) "I make many decisions on my own" are combined into one overall variable (additive index) called "professional autonomy". The two variables are highly enough correlated $(r=.487)$ to ensure that they measure the same underlying attributes and fulfil the level of reliability required. The index is ranged from 2 to 8 , and is treated as an interval level variable in the regression analysis.

In the analysis, position and gender, age and work experience are included as control variables. "Individual age" and "years of practice" are continuous variables, whereas the variables "gender" and "position" are dichotomies (0-1). A preliminary analysis was conducted to ensure no violation of the assumptions of multi-collinearity.

\section{Results}

The questions and statements presented in the following table measure the degree of various organizational and occupational control mechanisms, as perceived by social workers in the Norwegian social services.

Table 1 - Workers' perceptions of organizational control and management techniques, occupational control and work conditions ( $\mathrm{N}=620-626)$; percentage and mean

\begin{tabular}{|l|c|c|c|c|}
\hline Modes of governance & $\begin{array}{l}\text { Low degree/ } \\
\text { Seldom/Disagree }\end{array}$ & $\begin{array}{l}\text { Some degree/ } \\
\text { Sometimes }\end{array}$ & $\begin{array}{l}\text { High degree/ } \\
\text { Always/Agree }\end{array}$ & Mean \\
\hline Rules and directives (1-5) & 1 & 16 & 82 & 4.28 \\
\hline $\begin{array}{l}\text { Administrative work procedures and } \\
\text { agency routines (1-5) }\end{array}$ & 11 & 36 & 53 & 3.47 \\
\hline Politically defined objectives (1-5) & 4 & 19 & 77 & 4.13 \\
\hline $\begin{array}{l}\text { Instructed to achieve results and } \\
\text { production targets (1-4) }\end{array}$ & 9 & --- & 91 & 3.28 \\
\hline $\begin{array}{l}\text { Influenced by colleagues and professional } \\
\text { standards } \\
\text { (1-5) }\end{array}$ & 13 & 60 & 27 & 3.14 \\
\hline $\begin{array}{l}\text { Inadequate resources to complete the } \\
\text { tasks (1-5) }\end{array}$ & 17 & 46 & 37 & 3.25 \\
\hline Enough time disposal (1-4) & 70 & --- & 30 & 2.10 \\
\hline
\end{tabular}

Note: Originally, the responses varied on different scales from 1 to 5 and from 1 to 4 . In the presented table, the response categories are recoded: "High degree" and "Often" combine the response categories 4 and 5, while "Low degree" and "Seldom" combine the categories 1 and 2 on the 5-point scales. "Agree" combine the categories 3 and 4, and "Disagree" combines the categories 1 and 2 on the 4-point scales. 
As shown in Table 1, most practitioners in the social services completely agree (91\%) in being 'instructed to achieve results and production targets' (i.e. performance measurements) put forward by the central welfare administration. Moreover, social workers are subjected to a high degree to politically defined goals (77\%). On the other hand, social workers report a higher level of administrative control by rules and directives (82\%) than by work procedures and agency routines $(53 \%)$. The findings confirm the demands for efficiency and management in service delivery, both in terms of performance measurements, administrative rules and procedures. With regard to work conditions, $37 \%$ of the workers "always" experience a lack of adequate resources to complete their tasks, and many disagree in relation to having enough disposal time to get the work done (70\%). In addition, the choices and judgements of social workers are influenced by co-workers in many cases. According to the findings $60 \%$ report "to a certain degree", while $27 \%$ are "always" influenced by fellow colleagues.

\section{Public governance constraints and regulations on front-line discretion}

The OLS regression presented in the next table (2) shows how the various modes of governance embedded in the Norwegian welfare administration affect and regulate front-line practice. The dependent variable in this analysis is the additive index "professional autonomy", i.e. the sum of "freedom to decide how to carry out my work" and "I make many decisions on my own."

Table 2 - OSL regression: The relation between professional autonomy and modes of governance (organizational and occupational control), peer influence and work conditions

\begin{tabular}{|l|c|c|c|}
\hline \multicolumn{4}{|c|}{ Perceived autonomy of social service workers } \\
\hline \multicolumn{3}{|c|}{ B } & SE \\
\hline Organizational and occupational control: & \multicolumn{2}{c|}{ Sig } \\
\hline Rules and directives & $-.238^{\star * *}$ & .071 & .000 \\
\hline Politically defined objectives & .061 & .067 & .362 \\
\hline Performance measurements (output) & .133 & .078 & .089 \\
\hline Administrative routines and work procedures & $-.212^{\star * *}$ & .060 & .000 \\
\hline Peer influence & $.181^{*}$ & .073 & .013 \\
\hline Disposal time & -.001 & .071 & .988 \\
\hline Inadequate resources & -.035 & .061 & .564 \\
\hline Occupational position (manager=1) & $.501^{* * *}$ & .141 & .000 \\
\hline Work-experience (1-6 years) & -.006 & .038 & .871 \\
\hline Gender (woman=1) & -.212 & .129 & .100 \\
\hline Age (years) & -.006 & .004 & .210 \\
\hline Constant & 6.932 & .561 & .000 \\
\hline
\end{tabular}

Note: Unstandardized regression coefficients (B) and standard error (SE). Coefficients significantly different from zero are marked with ${ }^{*} p<0.05,{ }^{* *} p<0.01$, and ${ }^{* \star *} p<0.001$. Adjusted R. Square .070 . 
As shown in Table 2, four out of 11 independent variables make a significant statistical contribution to the model. The extent of "bureaucratic rules and directives" and "agency work procedures and routines" are negatively related to the extent of the professional autonomy of social service workers, while managerial position and peer influence are positively related. The analysis indicates that the peer influence of colleagues seems to have an increasing impact on workers' choices and judgements. Furthermore, the local managers exercise a significantly higher level of autonomy due to their holding of administrative positions compared to practitioners. The variables intended to measure the impact of New Public Management techniques in terms of politically defined objectives and by results (performance measurement) are not significantly related to the professional autonomy of social workers. With regard to the work conditions, the coefficients of "inadequate resources" and "disposal time" are not statistically significant. Similar to the individual characteristics of gender and work experience, the inadequate conditions do not restrict workers' ability and freedom to make decisions. In summary, the findings reveal that the traditional mode of governance has a negative and restrictive impact on professional autonomy in terms of rules and directives, whereas social work practice is not constrained by policy targets and performance management in a significant way (Table 2).

\section{Discussion and concluding remarks}

Following the Norwegian employment and welfare reform, there has been a shift in the steering focus from the overall goals to details of control and increased bureaucracy (Byrkjeflot, Christensen, \& Lægreid, 2011). On the one hand, requirements are set for more efficiency and outputs defined in measurable and quantifiable performance indicators. On the other hand, the new management model allows for more autonomy and flexibility in the use of allocated resources, and in the choice of means and measures (Lægreid, Roness, \& Rubecksen, 2006). The findings of this study reflect this dichotomy. Although the social service workers experience different forms of organizational control and instructions to achieve production targets (Table 1), they often make autonomous decisions about how to carry out their work (Table 2). Despite the requirements for achieving results and predefined targets, the new management techniques do not restrict front-line workers' freedom to make independent decisions in a significant direction (Table 2). The results indicate that the new management style 
(MBOR) allows practitioners to take more autonomous decisions than the other forms of traditional administration. The findings are both positive and negative in terms of professional autonomy. In the social services, discretion is regarded as necessary for a flexible and individualized treatment of clients to ensure that means are responsive to individual needs. In contrast, an extensive use of discretion in the application of laws and the provision of services can threaten the principles of predictability, legality and equal treatment, as well as making the democratic and political control more difficult (Banks, 2013). In a positive direction, procedures and notes of guidance may provide more clarity and focus, thereby enabling front-line workers to be more inclusive in the way information is shared. Concurrently, the demands for more effective accountability mechanisms are steadily increasing. Acting according to standard procedures or guidelines therefore depends on the ability and willingness of professionals to justify their behaviour.

According to the analysis, holding a managerial position increases the probability of the discretionary power of local managers. The findings are in line with the "new wave management" that emphasizes the need for a high discretionary power for professional managers to achieve results (Hood, 1991). During the reform, the managers became responsible for the coordination of services, and for achieving results and promoting the developmental changes required (Askim et al., 2010). As managers, they are both accountable to the main efficiency targets and responsible for the quality of services provided by the modern welfare administration (Harris \& White, 2009).

It is assumed that the targets and performance measures are primarily frameworks for action, implying that they are not too detailed or prescriptive, while still leaving room for professional autonomy. Within the social services, steering by performance measurement indicators is limited, and only covers some of the main aspects of the agencies' work. This is part of the reason why they do not appear to constrain or threaten the professional autonomy in a significant way. In the welfare administration, concrete performance indicators and production targets are mostly delimited to quotas for placements in training and qualifications programmes, as well as for activation plans. To achieve the predetermined targets and quotas, the social workers have to follow-up claimants in order to assess and clarify their individual work capability and employability, and to implement sanctions in situations of non-compliance. 
Activation targets in particular allow social workers to determine their own way of working towards the defined results. The scope for professional autonomy reported by social workers reflects the increase of activation strategies and measures embedded in the Norwegian policies and the new labour and welfare reform (Jessen \& Tufte, 2014). Following the main objectives of the reform, front-line workers are increasingly required to enforce activation policies and take measures towards clients, assessing and determining activation measures and sanctions, as well as eligibility claims. Discretionary decision-making occurs not only because technical limitations are in place to monitor street-level performance, but also because professionals are required to develop a workable policy in practice (Evans, 2011). Additionally, the activation measures are targeted at more groups than before, including long-term recipients of welfare benefits and social assistance with a substantially reduced work and earning capacity. Discretionary power is intentionally granted to the front-line services to ensure that the assistance and means are responsive to individual needs, to decide upon the methods of intervention, the use of means and requirements and the frequency of client contact in each case. Hence, the work-related activity requires a close and binding follow-up in a contractual manner that involves professional autonomy.

Furthermore, the findings indicate that professional fellowship and collegial authority play a significant role in guiding and regulating social work practice. The collective knowledge and shared beliefs of colleagues working within the social services provide a framework and support for interpreting individual cases and events that may justify decisions and increase the consistency of discretionary judgement across workers. Professional standards provide a basis for understanding and defining the appropriateness of action or the justification for inaction (Sandfort, 2000). Thus, the professional norms and ethical codes that influence and guide the practitioners' discretionary judgements may be more legitimate to social work practice than management measures and policy objectives.

Rules often embody matters of interpretation and discretionary choices concerning applications. Especially, in the cases of welfare benefits or services, where the rules are ambiguous or require complex assessments, the decision-making may involve simple interpretations in order to decide who satisfies the eligibility criteria (Lipsky, 1980). However, the specification of rules in terms of guidelines and directions make 
the rights less discretionary by clarifying their entitlement clauses (Molander \& Grimen, 2010). In particular, the increase of standard operating work procedures influences the application of rules by limiting the professionals' scope in decision-making (Table 2). In order to decide the eligibility for the time limited Qualification Allowance, caseworkers are obliged to follow a computer-based standardized procedure ${ }^{8}$ regulated by rules and regulations, assessing the clients' entitlements, disabilities and working capability.

However, the increase of rules, work procedures and guidelines may have practical and ethical implications. First, the demands for activation measures and quotas for placements may bring unintended consequences through skewed, informal and creaming practices as part of the front-line strategies to deal with their work (Brodkin, 2007; Lipsky, 1991). In consequence, the social work approach is challenged by less tolerance towards benefit dependency and the demand for more control and stricter follow-up to ensure inclusion through conditional welfare and labour market activation. Subjected to performance targets, the practitioner's focus may shift in order to fulfil the quotas numbers, pushing clients into qualification programmes and activation arrangements. As a result, the expanding use of predefined targets, quality standard procedures, standardized assessment forms, plans and contracts introduced in welfare services challenge the ability and opportunity for the individual practitioners to reflect on the ethics of individual choices and decisions

Moreover, the focus for the follow-up of clients is increasingly work-oriented (Van Berkel \& van der Aa, 2012; Thorén, 2008; Lorentz, 2001). Front-line workers have to participate in decision-making regarding which activation services to provide and which sanctions to choose. To enable the (re)entry of unemployed people into active work, social workers become institutional agents expected to adopt a strict approach to the regulation they enforce, rather than to operate within a more flexible understanding (Considine \& Lewis, 2010). For this reason, the changing political climate and increasing welfare-to-work approach challenge social work practice by transforming the social services into a more regulatory work field.

The demands for a stricter follow-up and implementation of activation plans imply the use of more choices and discretionary judgements in front-line services. Social service 
workers are instructed to assess work ability, considering conditions and the utility of different activation means and work programmes. Concurrently, the assessment made for providing the appropriate type of activation services in terms of benefit and followup has become partly standardized, and based on a more structured procedure for collecting information than before. The changes involved indicate that conditional requirements and norms of self-support have become the legitimate institutional standard for the follow-up of applicants, making the social work approach less creative and more disciplinary.

As professionals, social workers are supposed to make independent decisions about the best available measures for each client. As part of the employment and welfare administration, social workers are "objects" accountable for reaching the adopted policy objectives, in accordance with the main reform targets. For this reason, the conflicting demands challenge the ability and opportunity for the individual practitioners to exercise discretion according to the ethical and technical standards of social work. 


\section{Endnotes}

1) Hood (1991:3) lists seven overlapping precepts/components that appear in most discussions of NPM. Among these are "Hands on professional management" in the public sector and a stress on private sector styles of management practice, explicit standards and measures of performance, with a greater emphasis on output control, and a stress on a greater discipline and parsimony in resource use.

2) Public sector governance, including public management in a governance context, is defined as a "regimes of laws, rules, judicial decisions, and administrative practices that constrain, prescribe, and enable the provision of publically supported goods and services" (Lynn, Heinrich, \& Hill, 2001, p.7).

3) The Norwegian Parliament passed the NAV reform in 2005. In the following period from 2006 to the end of 2010 when the process was completed, a jointed front-line service was established in all municipalities. Overall, 457 local offices (one-stop shops) were established in each municipality (a total of 430). At the regional level, both administrative units and back-office units with special competencies were established, handling services defined as individual rights, primarily concerning pensions

4) Caseworkers employed in the social insurance and employment services are responsible for various benefits and supplements related to sickness and childbirth, unemployment, rehabilitation and disability, single parenthood, family and pension services, etc.

5) The term "professional autonomy" is related to the individual practitioner's freedom to act according to the professionally defined norms and standards of social work, which is different from the freedom to act in accordance with their own personal moral values and judgements about particular situations.

6) Since the data was collected in 2011 , the tasks and area responsibility of the social services are mainly the same, including the qualification programme targeted at long-term recipients

7) Management by work procedures and routines also involves standardized procedures and managerial control.

8) The Qualification Allowance (QA) is granted for participation in a Qualification Programme targeted at long-term recipients of social assistance, whose rights to national insurance benefits are limited. 


\section{References}

Askim, J., Christensen, T., Fimreite, A. L., \& Lægreid, P. (2010). How to assess administrative reform? Investigating the adoption and preliminary impacts of the Norwegian welfare administration reform. Public Administration, 47(2), 232-246.

Banks, S. (2004). Ethics, Accountability and the Social Professions. New York: Palgrave Macmillan.

Banks, S. (2013). Negotiating personal engagement and professsonal accountability: Professional wisdom and ethics work, European Journal of Social Work, 16(5), 587-604.

Brodkin, E. Z. (2007). Bureaucracy redux: Management reformism and the welfare state. Journal of Public Administration Research and Theory, 17(1), 1-17.

Brodkin, E. (2011). Policy work: street-level organizations under new managerialism. Journal of Public Administration Research and Theory, 17(1), 1-17.

Byrkjeflot, H., Lægreid, P., \& Christensen, T. (2011). Changing accountability relations in a welfare state: an assessment based on a study of welfare reforms. Bergen: Uni Rokkan Centre.

Christensen, T., \& Lægreid, P. (Eds.). (2001). New Public Management: The Transformation of Ideas and Practice. Aldershot: Ashgate.

Christensen, T., \& Lægreid, P. (2011). Democracy and administrative policy: Contrasting elements of New Public Management (NPM) and post-NPM. European Political Science Review, 3(1), 125-146.

Clarke, J., \& Newman, J. E. (1997). The Managerial State. London: Sage.

Clark, C. (2005). The Deprofessionalisation Thesis, Accountability and Professional Character. Social Work \& Society, 3(2), 182-190.

Considine, M., \& Lewis, J. M. (2010). Front-Line Work in Employment Services After Ten Years of New Public Management Reform. European Journal of Social Security, 12(4), 357-370.

Davis, K. C. (1969). Discretionary Justice: A Preliminary Inquiry. Baton Rouge, LA: Lousiana State University Press.

De Bruijn, H. (2011). Managing Professionals. London: Routledge

Evans, T. (2010). Professional Discretion in Welfare Services: Beyond Street-level Bureaucracy. Aldershot: Ashgate.

Evans, T. (2011). Professionals, managers and discretion: critiquing street-level bureaucracy- British Journal of Social Work, 41(2), 368-86. 
Evans, T., \& Harris, J. (2004). Street level bureaucracy, social work and the (exaggerated) death of discretion, British Journal of Social Work 34(6), 871-95.

Evetts, J. (2010). Reconnecting Professional Occupations with Professional

Organisations: Risks and opportunities. In J. Evetts, \& L. G. Svensson (Eds.), Sociology of Professions (123-145). Gøteborg: Daidalos.

Freidson, E. (1986). Profesional Powers: A study of the linstitutionalization of Formal Knowledge. Chicago: University of Chicago Press.

Freidson, E. (2001). Professionalism: The third logic. Polity Press, Cambridge.

Grimen, H. (2008). Profesjon og kunnskap [Profession and Knowledge]. In A.

Molander, \& L. I. Terum (Eds.), Profesjonsstudier (71-86). Oslo: Universitetsforlaget,.

Harris, J., \& White, V. (2009). Modernising Social Work: Critical Considerations. Bristol: The Policy Press.

Healy, K., \& Meagher, G. (2004). The reprofessionalization of social work: Collaborative approaches for achieving professional recognition. British Journal of Social Work 34,. 243-260.

Hill, M., \& Hupe, P. (2008). Implementing public policy: An introduction to the study of operational governance, 2nd edn.. London: Sage.

Hupe, P., \& Hill, M. (2007). Street-level bureaucracy and public accountability. Public Administration 85(2), 279-99.

Hood, C. C. (1991). A public management for all seasons?. Public Administration 69 Hjörne, E., Juhila, K., \& van Nijnatten, C. (2010). Negotiating dilemmas in the practices of street-level welfare work. International Journal of Social Welfare 19(3), 303309.

Jessen, J. T., \& Tufte, P.A. (2014). Discretionary Decisison-making in a Changing Context of Activation Policies and Welfare Reforms. Journal of Social Policy 43(2), 269-288.

Jewell, C. J. (2007). Agents of the Welfare State: How Caseworkers Respond to Need in the United States, Germany, and Sweden, New York: Palgrave Macmillan.

Johnsen, L., \& Yanca, S. (2001). Social work practice: A Generalist Approach, 7th edn. Boston: Allyn and Bacon.

Kuhlman, E. (2006). Traces of doubt and sources of Trust: Health professions in an uncertain society. Current Sociology 54(4), 607-620. 
Lipsky, M. (1980). Street-level Bureaucracy: Dilemmas of the Individual in Public Services. New York: Russell Sage Foundation.

Lenz, V. (2008). Welfare and Work Sanctions: Examining Discretion on the Front Lines. Social Service Review 82(2), 197-222.

Lipsky, M. (1991). The paradox of managing discretionary workers in social welfare policy. In M. Adler, C. Bell, J. Clasen, \& A. Sinfield (Eds.), The Sociology of Social Security (212-28). Edinburgh: Edinburgh University Press.

Lorentz, W. (2001). Social work responses to "new labour" in Continental Europien countries. British Journal of Social Work 31(4), 595-609.

Lægreid, P., Roness, P. G., \& Rubecksen, K. (2006). Performance Management in Practice: The Norwegian Way. Financial Accountability and Management 22(3), 251-269.

Lyngstad, R. (2013). Social work in municipalities: contested changes with implications for the profession?. Journal of Comparative Social Work 8(1).

Lynn, L. E., Heinrich, C. J., \& Hill, C. J. (2001). Improving governance: A new logic for empirical research. Washington, DC: Georgetown University Press.

May, P. C., \& Winter, S. C. (2009). Politicians, Managers and Street-level Bureaucrats: Influences on Policy Implementation. Journal of Public Administration and Research Theory 19(3), 453-476.

Molander, A., \& Grimen, H. (2010). Understanding professional discretion. In L. G.Svensson, \& J. Evetts (Eds.), Sociology of Professions: Continental and Anglo-Saxon Traditions. Gothenburg: Daidalos.

NOU 2004:13. (2004). En ny arbeids- og velferdsforvaltning [A New Employment and Welfare Administration]. Oslo: Statens forvaltningstjeneste, Informasjonsforvaltning

Pollitt, C., \& Bouckaert, G. (2004). Public management reforms. A Comparative Analysis. Oxford: Oxford University Press.

Sandfort, J. R. (2000). Moving beyond discretion and outcomes: Examining public management from the front lines of the welfare system. Journal of Public Administration Research and Theory 10(4), 729-756.

Scott, W. R. (2008). Lords of the Dance: Professionals as Institutional Agents, Organisational Studies. London: Sage.

Prop. 46 (2004-2005). (2005). Ny arbeids- og velferdsforvaltning [New Employment and Welfare Administration]: Tilråding fra Arbeids-og sosialdepartementet av 
11. mars 2005, godkjent $i$ statsråd samme dag. (Regjeringen Bondevik II). [Oslo]: Arbeids- og sosialdepartementet.

Styhre, A. (2013). Professionals Making Judgments: The Professional Skill of Valuing and Assessing. Palgrave: Macmillan.

Sosialtjenesteloven. (2007). Lov om sosiale tjenester [Social Services Act].

Sosialtjenesteloven. (2009) Lov om sosiale tjenester i arbeids- og velferdsforvaltningen [Social Services Act in the employment and welfare administration].

Svensson, L. G. (2010). Professions, organizations, collegiality and accountibility. In J. Evetts, \& L. G. Svensson (Eds.), Sociology of Professions (123-145). Gøteborg: Daidalos.

Thorén, K. (2008). Activation Policy in Action: A Street-level Study of Social Assistance in the Swedish Welfare State. Växjö: Växjö University Press.

Van Berkel, R., \& van der Aa, P. (2012). Activation work: Policy programme administration or professional service provision?. Journal of Social Policy 41(3), 493-510.

Vinzant, J. C., \& Crothers, L. (1998). Street-Level Leadership: Discretion and Legitimacy in Frontline Public Service. Washington, DC: Georgetown University Press.

White, V. (2009). Quiet challenges? Professional practice in modernised social work. In J. Harris, \& V. White (Eds.), Modernising Social Work: Critical Considerations, (129-144). Bristol: Policy Press. 